\title{
Restatement of the Law, Copyright: A Useful Resource for Practitioners and Courts or a Rashomon Exercise?
}

\author{
Eric J. Schwartz*
}

As the Ninth Circuit succinctly observed, when deciphering copyright law, "[w]e begin, as always, with the text of the statute." An examination of any aspect of copyright law commences with the text of Title 17 of the United States Code (the "statute"), and then turns to case law for adjudications and interpretations of the relevant statutory text, or as the primary source of law in the gaps in the statute. Everything else is secondary and not, of course, a substitute for the law, whether it is legislative history, Copyright Office (and other government agency) studies, treatises, or other commentary.

If copyright law consists predominantly of federal statute, how, if at all, will the American Law Institute ("ALI") project to prepare a Restatement of the Law of Copyright (the "Restatement") provide a useful or necessary resource for attorneys and the courts? In the face of the primacy of the enacted statutory text, why undertake a project to recast and rephrase the law? What, if any, use might it yield to practitioners and courts, and equally importantly, will consequential harms result?

From the inception of the Restatement project, the creative community has collectively viewed the project with skepticism about its necessity and fears about its purpose and biases, and the resultant impact on the livelihoods of creators. ${ }^{2}$ This

* Partner, Mitchell Silberberg \& Knupp LLC; former Acting General Counsel and Policy Planning Advisor, United States Copyright Office; President of the Copyright Society (2014-2016); Adjunct Professor of Copyright Law, Georgetown University Law Center and American University, Washington College of Law.

1. MDY Indus., LLC v. Blizzard Ent., Inc., 629 F.3d 928, 943 (9th Cir. 2010) (quoting Hawaii v. Off. of Hawaiian Affs., 556 U.S. 163, 173 (2009)).

2. See, e.g., Letter from Am. Photographic Artists et al. to ALI Officers and Directors (Oct. 14, 2015), https://perma.cc/3BS3-M7KS (signed by eighteen trade associations and guilds in the visual arts, motion picture, music, music publishing, and book publishing industries on behalf of their collective members opposing the ALI Restatement project from the outset.). Strong concerns about the Restatement's impact on copyright law have also been expressed by the U.S. Copyright Office and a bipartisan group of Members of Congress. See Letter from Karyn Temple Claggett, Acting Reg. of Copyrights, to ALI President David Levi et al. (Jan. 16, 2018), https://perma.cc/C6QU-6KHU; Letter from Sen. Thom Tillis, Rep. Ben Cline, Rep. Theodore E. Deutch, Rep. Martha Roby \& Rep. Harley Rouda to ALI Dir. Richard L. Revesz (Dec. 3, 2019), https://perma.cc/UG5U-RPP5.

(C) 2021 Schwartz. This is an open access article distributed under the terms of the Creative Commons Attribution-NonCommercial-NoDerivatives License, which permits noncommercial use, distribution, and reproduction, provided the original author and source are credited, and the article is not changed. 
Response focuses on the practical uses, if any, of the Restatement for attorneys and courts grappling with copyright issues. The Response also examines, from a practitioner's point of view, the Restatement's potential to harm the ecosystem of the copyright creative community, and the likelihood that the harm will outweigh any value the Restatement might bring to clarifying the law.

\section{CONCERNS WITH THE RESTATEMENT OF COPYRIGHT PROJECT}

In the past, ALI Restatements of Law have been useful resources for practitioners and staples in judicial decisions in nearly all U.S. courts. The history of the ALI and Restatements is well documented in the Article by Shyamkrishna Balganesh and Peter S. Menell in this Issue. ${ }^{3}$ As they note, since the founding of the ALI in 1923, Restatements have provided clarity and simplicity to common law (i.e., case law), in the form of succinct "black letter law" (i.e., text that synthesizes case law). Professor Joseph Liu notes the value of traditional Restatements as bringing "order, clarity, and coherence" to federal and state case law in common law disciplines. ${ }^{4}$

However, because copyright is overwhelmingly federal statutory law, it is illsuited for a Restatement intended to provide a synopsis of the entire corpus of the law. In addition, it is the historic authoritativeness of the ALI that ordinarily gives Restatements their credibility for courts and practitioners to cite to them as "the law" (or as fair an approximation of the law as is possible) in court filings and other legal documents. This Restatement, however, may never earn the presumptive credibility of common law Restatements. First, neither the Reporters nor the ALI have endeavored to articulate a coherent approach to "restating" a federal statute. As a result, the various drafts presented thus far have failed to treat the statutory text consistently or predictably. Second, to the extent it is possible to discern precepts underlying the departures of the black letter from the statute, they appear to favor restrictive interpretations of the existence and scope of copyright protection. Third, this begrudging exposition of copyright rules prompts the perception of anticopyright bias. Whether or not the perceived bias is real (and many would say it is), ${ }^{5}$

3. Shyamkrishna Balganesh \& Peter S. Menell, Restatements of Statutory Law: The Curious Case of the Restatement of Copyright, 44 COLUM. J.L. \& ARTS 285, 292-301 (2021).

4. Joseph P. Liu, Between Code and Treatise: The Hard Challenge of the Restatement of Copyright, 44 COLUM. J.L. \& ARTS 441, 441 (2021).

5. Those representing nearly the entirety of the creative class are questioning the purpose and even-handedness of this Restatement project overall and the ALI drafts to date. For instance, the Copyright Alliance, a nonprofit organization that represents over 1.8 million individual creators and over 13,000 organizations in the United States, has noted that the ALI Restatement drafters "are all of the shared misbelief that strong copyright protection is an obstacle to the public's ability to access and use creative works. This makes for a very unbalanced and one-sided restatement." Keith Kupferschmid, The Latest Battleground for Authors' Rights, AUTHORS GUILD (Mar. 13, 2018), https://perma.cc/PMP73TXX. The Author's Guild, an organization representing "novelists in all genres and categories, nonfiction writers, journalists, historians, poets, and translators," Who We Are, AUTHORS GUILD, https://perma.cc/9CCM-YBFT (last visited Mar. 13, 2021), expressed similar concerns: "We had nevertheless hoped that the drafters would take the higher road and not endow the Restatement of Copyright with their personal views, but that does not seem have [sic] transpired so far, especially in the 
the perception has contributed to the roiling controversy over the legitimacy of the undertaking and the credibility of the ALI.

In 1950, Akira Kurosawa directed the film Rashomon, which is itself a recasting of two short stories. The film depicts the story of a murder told and retold by various observers. These multiple subjective and contradictory points of view ultimately blur the truth of what actually happened. ${ }^{6}$ From my perspective as an experienced copyright practitioner counseling a wide spectrum of stakeholders in the creative community, this Restatement is headed towards the copyright law equivalent of Rashomon. ${ }^{7}$ It raises the specter of an alternative "black letter" publication-a Rashomon text - that is an interpretive but contradictory statement about an existing statute. If it remains on its current course with the statute reimagined, the Restatement will be neither useful nor used by knowing practitioners and judges, and for those unaware, it will result in confusion and ambiguity about the law. If judges do use it, the Restatement could also, given its widely-perceived biases, undermine essential rights and protections for creators and producers.

These concerns are not unfounded. Even if not steeped in the origin story of the Restatement project, nor the actual motives behind it, any observer within the copyright community can see signs of trouble. ${ }^{8}$ For the past several decades, the copyright community has become increasingly polarized between the traditional creative community (creators and producers) and digital disseminators and others reliant on creative works they do not create (search engines, social media platforms, etc.). The impetus for the Restatement project did not come from the copyright creative community, which, as noted, has been almost universally opposed to this undertaking. ${ }^{9}$ However well-intended the ALI might be in its public purpose to assist in understanding existing law, the creative community sees this exercise as a step towards recasting and thus ultimately revising the law to the detriment of creators and producers, deepening the rifts within the copyright community. As the late

case of the lead reporter, [Christopher] Sprigman. Now that we are in our fifth year of the project, the pattern is clear. The bias against copyright protection is often subtle with respect to the cases and areas of the law the drafters focus on and what they leave out. But there are other areas where this bias is not so subtle, such as where a minority view is adopted over a majority view that favors copyright protection, or where a new rule is made up by the reporters and inserted as if it were law, and where the interests of copyright owners are disregarded." Concerns Over Anti-Author Bias in ALI's Copyright Restatement, AUTHORS GUILD (Sept. 24, 2020), https://perma.cc/JH7A-39SR.

6. See RASHOMON (Daiei Film 1950). The film is based on short stories by Ryunosuke Akutagawa: In a Grove (1921) and Rashomon (1915). Ryunosuke Akutagawa, In a Grove and Rashomon, in The EsSEnTial AKutagawa 3, 103 (Seji M. Lippit ed., 1999).

7. My clients are creators, producers, and distributors in the film, television, music, music publishing, book publishing, and video game industries. In addition to creators and producers, my clients have included dozens of public and private libraries and archives on issues pertaining to the collection, preservation, and making available of copyright materials, as well as counseling many others in the "user community." See David Montgomery, Eric J. Schwartz's Love of Film Fueled His Push for Preservation of Old Movies, WASH. POST (Aug. 12, 2011), https://perma.cc/88VU-JL3T.

8. See e.g., Letter from Prof. Pamela Samuelson to ALI Dir. Lance Liebman (Sept. 12, 2013), https://perma.cc/2HXX-NTAE [hereinafter Samuelson Letter] (suggesting a possible "Principles of Copyright Project" and subsequently referring to it as a "foundation for copyright reform"); Justin Hughes, Restating Copyright Law's Originality Requirement, 44 COLUM. J.L. \& ARTS 383, 386-87 (2021).

9. Samuelson Letter, supra note 8. 
Justice Antonin Scalia wrote in a 2015 dissent, "modern" Restatements "are of questionable value, and must be used with caution"; they have strayed from "describing the law, and have chosen instead to set forth their aspirations for what the law ought to be." 10 To the extent these biases were baked into the foundation of this Restatement, they signal not just caution, but significant problems for the utility, if any, of the final document of this undertaking.

The question then is whether there are salvageable portions of the Restatement that can nevertheless be viewed as reliable and useful to the courts and practitioners for whom the Restatement is intended, and whether the value of those materials outweigh the potential harm to the creative community.

The corpus of the copyright law of the United States can be broken roughly into two components: the predominant federal statutory law crafted by Congress and the judicial component crafted by the courts. ${ }^{11}$ The judicial component consists of interpretations of the statute, as well as judicial lawmaking in the gaps of the statute, including, for example, in the limited areas of federal or state common law not otherwise preempted by $\S 301 .^{12}$ State (common or statutory) law remains in only very few, mostly historical, pockets; for example, regarding the treatment of preFebruary 15, 1972 sound recordings. ${ }^{13}$ One method to examine the potential usefulness of the Restatement is to segregate it, where possible, into these two elements: (1) the statute and (2) the judicial law, including the common law niches of copyright. ${ }^{14}$

10. Kansas v. Nebraska, 574 U.S. 445, 475 (2015) (Scalia, J., concurring in part and dissenting in part) (taking issue with the majority's reliance on the Restatement (Third) of Restitution and Unjust Enrichment).

11. Each component has its respective constitutional authority. Compare U.S. CONST. art. I, § 8, c1. 8 ("The Congress shall have Power ... To promote the Progress of Science and useful Arts, by securing for limited Times to Authors and Inventors the exclusive Right to their respective Writings and Discoveries."), with U.S. CONST. art. III, § 2, cl. 1 ("The Judicial Power shall extend to all Cases, in Law and Equity, arising under this Constitution, [and] the Laws of the United States ....").

12. See 17 U.S.C. § 301(a) ("On and after January 1, 1978, all legal or equitable rights that are equivalent to any of the exclusive rights within the general scope of copyright as specified by section 106 in works of authorship that are fixed in a tangible medium of expression and come within the subject matter of copyright as specified by sections 102 and 103, whether created before or after that date and whether published or unpublished, are governed exclusively by this title. Thereafter, no person is entitled to any such right or equivalent right in any such work under the common law or statutes of any State.").

13. This is true, if even narrower, after the 2018 enactment of the Music Modernization Act (MMA) which partially federalized these recordings. 17 U.S.C. §301(c) ("“ $\mathrm{N}]$ o sound recording fixed before February 15,1972 , shall be subject to copyright under this title. With respect to sound recordings fixed before February 15, 1972, the preemptive provisions of subsection (a) shall apply to activities that are commenced on and after the date of enactment of the Classics Protection and Access Act. Nothing in this subsection may be construed to affirm or negate the preemption of rights and remedies pertaining to any cause of action arising from the nonsubscription broadcast transmission of sound recordings under the common law or statutes of any State for activities that do not qualify as covered activities under chapter 14 undertaken during the period between the date of enactment of the Classics Protection and Access Act and the date on which the term of prohibition on unauthorized acts under section 1401(a)(2) expires for such sound recordings. Any potential preemption of rights and remedies related to such activities undertaken during that period shall apply in all respects as it did the day before the date of enactment of the Classics Protection and Access Act.").

14. This rough triage analysis of the components of copyright law puts the very limited state law issues on the sidelines. 
The congressionally enacted text of Title 17, including over fifty internal definitions ${ }^{15}$ is several hundred pages long. The language of the statute was drafted word for word (including major revisions in 1909 and 1976, as well as all other amendments) after negotiations by Members of Congress, congressional and Copyright Office staff, and outside interested parties. ${ }^{16}$ From the drafts that are publicly circulating, the Restatement intends ultimately to include a restating of much or all of this statutory law, including subject matter ( $\S \S 102-104)$; initial ownership, transfers, and licenses ( $\S$ 201-205); duration ( $\S 301-305)$; rights and exceptions ( $\S 106-122)$; remedies ( $\S 501-505)$; and perhaps most perplexingly, a restating of some of the $\S 101$ definitions.

Initial drafts of the Restatement have inconsistently paraphrased, omitted, or in some cases completely adopted verbatim the text of the statute. This ambiguous methodology alone demonstrates why the statutory portions of the Restatement in particular will not be useful for practitioners and courts. ${ }^{17}$ Restating or paraphrasing (or omitting) congressionally-made law is not something practitioners or courts can rely on, as it will merely mislead or confuse users of the Restatement. These same shortcomings will be especially problematic for practitioners and judges less conversant with copyright law. The Restatement will present judges with rephrased and restructured text in lieu of the statute. Judges, relying on the ALI's reputation but unfamiliar with the statute, may not understand how the Restatement's infidelities to statutory text can substantively alter the law. As such, it would be a mistake to rely on or cite to those portions of the Restatement that rework the statute in lieu of reproducing the actual statute.

The second element of copyright consists of judicial interpretation of the statute, or in some instances judicial lawmaking. ${ }^{18}$ A synopsis of case law, for example,

15. 17 U.S.C. $\S 101$. In addition to $\S 101$, there are a few other internal definitions in the statute. See, e.g., id. §1201(a)(3) (stating what it means "to "circumvent a technological measure").

16. A personal first-hand observation serving as staff at the Committee on Rules, U.S. House of Representatives (1979-1988) and at the U.S. Copyright Office (1988-1994), working on or closely observing others drafting and enacting numerous laws. At the Copyright Office, for example, this included working with congressional staff and Copyright Office colleagues on the drafting of the Berne Convention Implementation Act of 1988, Pub. L. No. 100-568 § 2, 102 Stat. 2853 (codified as amended at 17 U.S.C. $\S 101$ et seq.), the Visual Artists Rights Act (new § 106A), 17 U.S.C. § 106A, the Copyright Renewal Act of 1992, Pub. L. No. 102-307, $\S \S 101-02,106$ Stat. 264 (codified as amended in scattered sections of 17 U.S.C.), and the Uruguay Round Agreements Act (sometimes referred to as the GATT Implementation Act) (new § 104A), Pub.L. No. 103-465, 108 Stat. 4976 (codified as amended at 17 U.S.C. § 104A).

17. The statutory restatement methodology and inconsistencies are a serious flaw in the draft Restatement, noted by many in the copyright bar. See, e.g., Letter from June Besek \& Jane Ginsburg to ALI Reps. Regarding Tentative Draft 1 (TD1) of the Restatement of the Law, Copyright, 1-2 (July 16, 2020) ("The most fundamental concern remains the one we and many other Advisers - as well as the U.S. Copyright Office, the U.S. Patent and Trademark Office, the American Bar Association's Section of Intellectual Property Law, the New York City Bar Association's Committee on Copyright and Literary Property and others-have raised from the start: The ALI has neither in general, nor with respect to this Restatement, developed any coherent or perceptible methodology for how to restate a statute. As a result, the relationship of TD1 and its predecessors to the U.S. Copyright Act has been highly inconsistent, not to say erratic.").

18. There are many examples of judicial statutory interpretation. See, e.g., Mazer v. Stein, 347 U.S. 201 (1954) (parsing the line between protection and precluded protection for a "useful article," later defined in the 1976 Act in $\S 101$, and additionally in the definition of a "pictorial, graphic or sculptural 
parsing or annotating actual statutory language, would be helpful in a Restatement, but not if the Restatement has also restated the statute on which the cases are opining. The more these segments in the Restatement become interpretive, or worse, biased reworkings, the less useful they will be to practitioners and courts. Also, as with the statutory segments, the less conversant the practitioner or court is with copyright law generally, the more likely they will be to rely on the Restatement as an accurate reflection of law, and thus the greater the potential harm to all parties and to the copyright system from a Restatement that, instead of adopting statutory text, approximates or even skews it.

The ALI's reputation and imprimatur usually make its Restatements authoritative resources not just to understand the law, but to be used in filings and citations as definitive statements of the law. That is the major difference between restatements and treatises. Treatises are valuable research tools for practitioners and courts, but only ALI Restatements (in common law disciplines), distill the case law into "black letter" law. ${ }^{19}$ However, this Restatement, even if it were limited to just the case law components of copyright, still must confront a significant obstacle to its credibility: Many of the "common law" features of copyright law nonetheless build upon statutory rules; if those rules are unreliably restated, the case distillation becomes tainted at its source. Second, even in the areas of judicial law not interpreting the statute, the draft Restatement shows signs of error according to a multitude of comments by ALI Advisers and other copyright experts. ${ }^{20}$

work"); Star Athletica, L.L.C. v. Varsity Brands, Inc., 137 S. Ct. 1002 (2017) (same). Another example pertains to copyright termination where courts have delineated rules for those agreements that fall within the statutory prohibition against an "agreement to the contrary" that attempts to negate termination rights. See 17 U.S.C. § 203(a)(5) (grants executed on or after January 1, 1978); id. § 304(c)(5) (grants made prior to 1978); Marvel Characters, Inc. v. Simon, 310 F.3d 280, 289-91 (2d Cir. 2002) (refusing to enforce a settlement agreement effectively waiving termination rights, finding the agreement to be "an agreement to the contrary"); Classic Media, Inc. v. Mewborn, 532 F.3d 978, 983-90 (9th Cir. 2008) (refusing to give a settlement agreement the effect of waiving termination); Milne v. Stephen Slesinger, Inc., 430 F.3d 1036, 1043-44 (9th Cir. 2005) (distinguishing Marvel finding a waiver of the termination right because a renegotiation of rights was undertaken in lieu of termination and is not an "agreement to the contrary").

19. Those more practiced in law (in any area of law) use treatises, and presumably restatements, only as a confirmation of what they already know, or for added insight or alternative views. For unresolved areas of law (because of statutory or judicial silence, or circuit splits), all guides and other resources offer another opinion: an educated approximation of the law. However, credible and authoritative restatements can be a valuable source for general use and citation.

20. See, e.g., Letter from June Besek \& Jane Ginsburg to ALI President David Levi et al., Re: Council Draft 5 (CD5) of the Restatement of the Law, Copyright (Jan. 13, 2021). Unfortunately, many of the Adviser submissions are not publicly available. See also Letter from Judge M. Margaret McKeown to ALI Reps. and Advisers, Re: Preliminary Draft 6 (PD6) (Sep. 14, 2020); Letter from Judge M. Margaret McKeown to ALI Council, Reps. and Advisers, Re: CD5 (Jan. 17, 2020); Letter from George W. Jordan III, Chair of the Am. Bar Ass'n Section on Intell. Prop. L., to ALI President David Levi et al. (Oct. 8, 2019), https://perma.cc/ZL64-32WD; Letter from Judge M. Margaret McKeown to ALI Council, Re: CD3 (Oct. 9, 2019); Letter from Adviser Dale Cendali to ALI President David Levi and Council Members, Re: CD 3 (Oct. 18, 2018); Letter from Mark K. Dickson, Chair of the Am. Bar Ass'n Section on Intell. Prop. L., to ALI President David Levi et al., at 3 (Oct. 3, 2018), https://perma.cc/LDW7-6EQW; Letter from Advisers Simon Barsky, Jacqueline Charlesworth, Michael Fricklas, Janet Fries, Dean Marks, Steven Marks, Mickey Osterreicher, Mary Rasenberger, Jay Rosenthal \& Ben Sheffner to ALI Dir. Richard L. Revesz et al., Re: Restatement of the Law, Copyright (Jan. 9, 2018), https://perma.cc/X4R9-MHQP; Report by the N.Y. State Bar, Copyright and Literary Prop. Comm., Recommendation to Reject the 
In one manner, all ALI Restatements face the same impediments in their case synopses as any treatise. No matter how impartial or precise, the drafters of Restatements are offering a distillation of extensive case law (made even more complicated in this Restatement, which distills statutory text with a case law overlay). However, even if the Restatement were limited just to a case law synopsis, there is much to synthesize and also much to interpret given the extensive case law dating from the first copyright statute (the Copyright Act of 1790). As with any wellrespected treatise, it is still a synopsis of law-entailing authors' decisions on omissions or inclusions of relevant materials and cases, and characterizations of included cases, all melded with the opinions and biases of those authors. ${ }^{21}$ Ultimately, the Restatement is law viewed through the lens of pre-selected authors, and, like a treatise, its authors have biases; however, treatises do not purport to be an approximation of "the law."

There is another difference between traditional common law restatements and this Restatement. Copyright is a very specialized area of law. The ALI Council and membership are proficient in the traditional restatement core areas of the law and are thus able to correct overt or unintentional reporter biases, but given the Council's and the membership's general unfamiliarity with copyright law, that safety net may fail for this Restatement. If the Reporters choose to disregard the Advisers, there may be no subsequent institutional review capable of keeping the work on an even keel. The practical concern is that if the Restatement, as feared, veers away from actual law and more into aspirational law, it will be incorporated into federal decisions by lay judges unaware, thereby becoming the law. In this manner, the Rashomon effect will lead to a back-door revision of law.

\section{COMMON LAW AREAS OF COPYRIGHT LAW WHERE A RESTATEMENT COULD BE USEFUL}

If the restating of the statute in the draft Restatement is not salvageable, what about the other component of judge-made copyright law: the common law portions of the draft? Although not as substantial proportionally to copyright jurisprudence as the statute, the common law comprises several essential areas of copyright for practitioners and courts. Examples include the constitutional prerequisite for copyright protection of "originality" and the many court-drawn tests for determining "substantial similarity" between two works. ${ }^{22}$ Even this area of law can be further

American Law Institute's Proposal To Create a Restatement of Law, Copyright (Jan. 2018), https://perma.cc/Z282-GQHZ.

21. Since 1998, I have authored and annually revised a $200+$ page summary of U.S. copyright law in Paul Edward Geller \& Melville B. Nimmer, International Copyright LaW and Practice (2020). The U.S. law chapter, one of the twenty-three in-depth national law summaries in the treatise, can cover only some of the relevant case law (even with over 1,100 footnotes), which means that some cases are included, some are omitted, and some are truncated. It is a distillation of law, but by no means a substitute for the law.

22. For the Supreme Court's defining of the constitutional prerequisite of "originality," see Feist Publ'ns, Inc. v. Rural Tel. Serv. Co., 499 U.S. 340 (1991) (refusing copyright protection to alphabetical listings of a telephone directory as falling below the threshold of minimal creativity). There is also the 
delineated into areas for which there is no statutory guidance, such as originality and substantial similarity, and areas in which the statue provides some indicia but leaves much to judicial interpretation, such as fair use. Distilling and synthesizing common law in both areas in an unbiased Restatement would be useful to courts and practitioners.

Here, in more detail, are three examples of judicially-made law (in areas of both some and no statutory indicia), all critically important for practitioners and courts, and the potential usefulness of the Restatement for these areas of law: (1) the first prong of the $\S 101$ definition of a "work made for hire"; (2) fair use, found in $\S 107$; and (3) third-party liability case law.

\section{A. First Prong of Work Made for Hire}

As clarified in Community for Creative Non-Violence v. Reid, there are "two mutually exclusive ways for works to acquire work-for-hire status: one for employees and the other for independent contractors." ${ }^{23}$ The definitions in $\S 101$, in the so-called first prong (first paragraph), define a work made for hire to include "a work prepared by an employee within the scope of his or her employment." 24 In Reid, the Supreme Court looked to the federal common law of agency to determine such employment, weighing multiple factors.

The Reid case referred to the non-exhaustive list of factors in the Restatement (Second) of Agency, none alone determinative, to tease out these factors, including, inter alia, the hiring party's control over the work and the regular business of the employer. Thus, one of the areas where a Restatement of Copyright could be useful-defining an employee-is ground already well-covered in the existing Restatement (Second) of Agency. But the ALI has since promulgated a Restatement (Third) of Agency whose factors are not identical to the ones the Supreme Court adopted in Reid. The agency factors in the draft Restatement of Copyright toggle between the two Restatements of Agency, instead of focusing on the Supreme Court and subsequent case law relying on Reid. This inter-Restatement conflict will need to be resolved to avoid confusion so that the Restatement of Copyright remains faithful to copyright case law, which, post Reid, derives from the earlier Restatement

separate semantic question of whether "originality" (i.e., not copied from the work of another author) is an adjunct to or a separate element of "creativity" as defined in Feist. 1 NIMMER ON COPYRIGHT § 2.01[B] ("[G]reater clarity of expression is perhaps achieved by regarding originality and creativity as separate elements"). The courts have crafted several tests in phases to define and analyze "substantial similarity"not mentioned or defined in the statute. The tests generally involve first removing unprotected materials from consideration (i.e., the "abstractions" test), then assessing the similarity between the protected plaintiff's work and materials allegedly infringing found in the defendant's work; and with many iterations, additionally regarding general public and expert witnesses and the like. Courts have been wrestling with the boundaries of substantial similarity for a long time. See, e.g., Nichols v. Universal Pictures Co., 45 F.2d 119, 121 (2d Cir. 1930) ("Nobody has ever been able to fix that boundary, and nobody ever can.").

23. 490 U.S. $730,741(1989)$.

24. 17 U.S.C. $\S 101$. 
(Second) of Agency. The end result of the Restatement should be clear black letter law reflecting the copyright treatment to usefully guide courts and practitioners. ${ }^{25}$

\section{B. FAIR USE}

Section 107, the codification of common law fair use rooted in equity principles, enumerates the four nonexclusive factors. ${ }^{26}$ Ordinarily, a Restatement with a synopsis of this essential case law, as in other areas of common law, would be useful - in this instance, synthesizing the myriad fair use cases and precedents.

However, as the Supreme Court noted, although the fair use factors may be a "gauge for balancing the equities," the Court further acknowledged that "each case raising the question must be decided on its own facts." 27 In this way, the Court admonished that this "task is not to be simplified with bright-line rules," but rather in "case-by-case analysis" in which the four factors "are to be explored, and the results weighed together, in light of the purposes of copyright." 28

This fact-based reliance is what makes a Restatement (or other synthesis) of fair use cases useful, but not demonstrably so, for practitioners (or courts). The Restatement would provide a helpful first step (assuming it is offered in an unbiased manner) as an amalgamation and summary of cases and precedents, especially for cases decisively decided. But, the corpus of fair use case law is large and inconsistent at the lower courts (sometimes contradictory, with short segments being deemed "unfair" and longer ones "fair" in similar usage). The cases are very fact-based and evolve with technological change, making older cases obsolete. Even with similar fact patterns, practitioners advising clients particularly on fair use calculations know that the four factors are only a part of the consideration. Other, often more important factors - that no Restatement could capture - must be assessed before rendering risk-

25. See Reid, 490 U.S. at 751-52 (1989) (referring to the non-exhaustive list of factors in the Restatement (Second) of Agency). See also ReStATEMENT (ThiRd) OF AGENCY § 707(3)(a) (AM. L. INST., 2006).

26. The Statute reads:

[T] he fair use of a copyrighted work ... for purposes such as criticism, comment, news reporting, teaching (including multiple copies for classroom use), scholarship, or research, is not an infringement of copyright. In determining whether the use made of a work in any particular case is a fair use, the factors to be considered shall include:

(1) the purpose and character of the use, including whether such use is of a commercial nature or is for nonprofit educational purposes;

(2) the nature of the copyrighted work;

(3) the amount and substantiality of the portion used in relation to the copyrighted work as a whole; and

(4) the effect of the use upon the potential market for or value of the copyrighted work.

The fact that a work is unpublished shall not itself bar a finding of fair use if such finding is made upon consideration of all of the above factors.

17 U.S.C. § 107. The factors are illustrative only. See id. § 101 (defining the terms "including" and "such as").

27. H.R. REP. No. 94-1476, at 65. (1976); Sony Corp. of Am. v. Universal City Studios, Inc., 464 U.S. 417, 448 n.31 (1984).

28. Campbell v. Acuff-Rose Music, Inc., 510 U.S. 569, 577-78 (1994). 
assessment judgment to a client, including industry practices (and sub-sector practices; for example, documentary film versus feature film practices), the litigious nature of the parties involved, and some other factors unrelated to case law.

This is why, in practical terms, practitioners advising on fair use appreciate the limits of case law summary, no matter how authoritative. In this way, the Restatement, even if well-balanced, would not supersede already available treatise materials that amply cover this area and which are annually updated with case developments. For pragmatic reasons, its authority would not be relevant for counseling clients (a statement by scholars of "the law" would not be relied on), nor probably for courts. This is because courts commence fair use cases afresh due to their heavy reliance on the facts and the four factors, unless a precedential case falls squarely in the current-case fact pattern.

\section{THIRD-PARTY LiabiLITY}

This area of common law is certainly an essential component of copyright enforcement practice. While the statute provides clear "direct" liability, it merely references, but is otherwise silent on, the nature or scope of third-party liability. ${ }^{29}$ The copyright statute provides that the owner of copyright has the exclusive rights "to do and to authorize" any of those rights. ${ }^{30}$ That "authority" is the genesis of thirdparty copyright liability that the courts have expanded upon and advanced from other areas of law, such as tort law.

As developed by the courts, parties who do not themselves infringe may nonetheless incur liability for vicarious infringement or contributory liability for an infringing act that another party commits directly. Vicarious, contributory, and inducement liability law are based, each, on long lines of case law. ${ }^{31}$ These cases have defined the factors for such liability, including, for vicarious liability: (1) the defendant's degree of control over the direct infringer; and (2) the direct financial benefits resulting from the direct infringement. For contributory liability, the factors include: (1) the contribution of machinery or other devices or goods used to infringe; and (2) personal conduct that furthers infringement by either inducing it, or knowingly forming a part of the infringement. ${ }^{32}$

Although not yet a part of the draft Restatement project, this is one instance where an unbiased synthesis of the case law could be valuable to practitioners and courts

29. 17 U.S.C. §501(a) ("Anyone who violates any of the exclusive rights of the copyright owner ... is an infringer....").

30. Id. $\$ 106$.

31. See, e.g., Shapiro, Bernstein \& Co. v. H.L. Green Co., 316 F.2d 304, 307 (2d Cir. 1963) (finding vicarious liability "[w]hen the right and ability to supervise coalesce with an obvious and direct financial interest in the exploitation of copyrighted materials"). Many other cases have followed in the "hard copy" and digital copy eras of copyright. See, e.g., Fonovisa, Inc. v. Cherry Auction, Inc., 76 F.3d 259, 262-63 (9th Cir. 1996) (finding defendants liable for the financial benefits accrued from admission fees to a swap meet providing customers with cheap counterfeit musical recordings).

32. See Metro-Goldwyn-Mayer Studios, Inc. v. Grokster, Ltd., 545 U.S. 913, 940 (2005) (finding liability for a distributor of peer-to-peer software because, inter alia, it induced infringement); A\&M Recs., Inc. v. Napster, Inc., 239 F.3d 1004 (9th Cir. 2001) (finding vicarious liability, as well as contributory liability for providing a directory of available users and songs accessible through a website). 
summarizing the state of law on key elements of "knowledge" and "control" and other factors that have been extracted by case law. However, this is the area of law most wrought with rifts (and lawsuits) between the traditional copyright creative community and "big technology." Given these rifts, any perception that the Restatement leans toward one of the contending interests will undermine the Restatement's utility and authoritativeness.

The usefulness of a Restatement is further hampered by some critical omissions. First, for whatever reason, the drafts do not cite or rely on some important and impartial U.S. Copyright Office studies and materials. For example, there is no reliance on the extensive "making available" study that the Office prepared to describe the scope of rights. ${ }^{33}$

In other areas, the draft Restatement not only does not defer to the Copyright Office, it has all but written the Office out of the draft-even though the Office's regulatory law (or pronouncements) are routinely relied upon by practitioners and courts. For example, practitioners and courts know that "Office practice"- the Office's practices for registrations and recordations - requires an understanding of Office regulations and internal decision-making practices. The two best sources for that are the regulations (in the Code of Federal Regulations) and the Compendiumcompletely revised in 2017 (and further revised in 2021). ${ }^{34}$ In addition to the regulations, the Compendium provides insight and guidance on the Copyright Office's internal policies regarding copyright registrations, recordations, and other of its essential tasks. The regulations and Compendium do not need to be "restated" but rather are primary source materials for anyone practicing before the Copyright Office. ${ }^{35}$ Taken together, the Restatement's inconsistent relationship with authoritative sources of copyright law-such as the statute, Copyright Office regulations, etc. - only undermines the authority and usefulness of the Restatement. In sum, if its interpretation of case law is inaccurate - or where case law diverges, not evenhanded (taking minority views) — and it gives short shrift to authoritative Copyright Office interpretations, can it be trusted by its intended readers?

33. U.S. COPYRight OFF., The MAKing AVAilable Right in the United StATES: A RePORT OF THE REGISTER OF COPYRIGHTS (Feb. 2016).

34. See Copyright Office Procedures, 37 C.F.R. $\S \S 201-212$ (2020); U.S. CopYRIGHT OfF., COMPENDIUM OF U.S. COPYRIGHT OFFICE PRACTICES (3d ed., 2021).

35. Restatements, unlike other legal resources, do not provide pragmatic guidance to attorneys on practice tips or recommendations, for example, on how to navigate Copyright Office registration or recordation systems. But, the Restatement should at least properly detail some of the Office's key practices and regulations, since these can have significant legal consequences for creators and users of copyrighted material, in transactional and litigation matters. 


\section{HOW, THEN, WILL PRACTITIONERS AND COURTS BE ABLE TO MAKE ANY USE OF THE RESTATEMENT?}

One option is to downsize the scope of the project to a traditional ALI common law case Restatement. If done properly and without bias, this would provide a useful tool for courts and practitioners with valid "black letter" law ordering the federal case law. Another very smart suggestion is to merely "quote the relevant portion[s] of the text of the statute" and to annotate the code with "relevant legislative history and other interpretive materials, before moving to the usual Comments and Reporters' Notes." ${ }^{36}$ A third option is to convert the entire undertaking into a copyright ALI Principles Project whose aspirational nature (on what copyright law should be in the eyes of its drafters) would not need to hide behind misleadingly "neutral," but in fact selective or biased "restatements" of law. A fourth (and perhaps last resort option) is also highly impractical. If the process continues its current course, it may fall on the collective creative community to draft its own counter-Restatement: that is, a user's manual to alert the bar and courts to the omissions, anomalies, and disputable features of the Restatement. It would not enjoy the presumptive credibility or legal authority of a traditional ALI Restatement. But, if it were possible to extensively annotate the Restatement-including the deviations from the actual statute, and the misuse of case law (minority views in lieu of majority views, etc.) - readers would know the portions they could reliably use, and the segments (likely significant portions) of the Restatement to ignore.

Nonetheless, the ALI is expecting judges and practitioners to rely on the Restatement when it is completed. Since all of these deficiencies have remained throughout the five-year drama to get partial drafts of a Restatement moving towards approval, why is the project continuing if copyright practitioners - and perhaps judges aware of the shortcomings - will avoid using or relying on the final product? One reason is the obstinate view that the Restatement, when completed, and regardless of the quality and validity of its final product in the eyes of the knowledgeable practitioners, will be used because of the historic reputation of the ALI.

Another possible answer lends some credence to the suspicions of the true purpose of the Restatement from its inception: as an end-run around Congress to significantly revise the (actual) current copyright law. ${ }^{37}$ In a September 2014 memorandum, Professor Christopher Sprigman, now the current Principal Reporter for the Restatement project, wrote that "by most accounts, copyright law is in a bad state, and has been for some time," further noting the square peg, round hole fit of a "20th

36. Liu, supra note 4, at 442 (citing Balganesh \& Menell, supra note 3).

37. Doing so is a far cry from a "subtle" transformation of copyright law, contrary to the ALI's self-described rationale for any Restatement: "Webster's Third New International Dictionary defines the verb 'restate' as 'to state again $o r$ in a new form' [emphasis added]. This definition neatly captures the central tension between the two impulses at the heart of the Restatement process from the beginning, the impulse to recapitulate the law as it presently exists and the impulse to reformulate it, thereby rendering it clearer and more coherent while subtly transforming it in the process." RESTATEMENT OF THE LAW, COPYRIGHT, at xii (AM. L. INST., Council Draft No. 4, Dec. 3, 2019) [hereinafter Restatement Council Draft No. 4 (2019)]. 
century" law with "21st century" digital technologies. ${ }^{38}$ If this is, in fact, the ulterior purpose for the Restatement, it takes up a common refrain echoed for years by many in the "big-tech" and user communities. ${ }^{39}$ It is a mantra of digital platforms and services (social media companies, search engines, etc.) that copyright law is too protective of authors and producers and somehow this translates to being both harmful to and out of touch with the needs of the consuming public and public access to copyrighted works.

But, is there really a crisis requiring a major overhaul of the copyright system? Here is how badly this 20th century copyright law is "failing" the public and consumers: More creative content is now legally available, in more diversified ways, and with more varied pricing options than at any other time in history, for the enrichment and enjoyment of consumers.

As one example: At least sixty million songs are available to the public on dozens of legal services, some on subscription tiers, but also much of it on a free tier (i.e., advertisement-based services), more than at any time in the history of music. The same is true for films, where more feature, documentary, and independent film and television content is now available than at any time since the dawn of moving image technology in the late nineteenth century. It is also the case in book publishing, video game publishing, and other educational and entertainment industries - more content is legally available, and at different consumer price points (including free), than ever before. If the question for the Restatement proponents is whether the law is meeting its constitutional underpinning to "promote the progress" of science (i.e., knowledge) in the creation and dissemination of material to the public, the answer is absolutely "yes." 40 This is not just a phenomenon in the United States, but worldwide, and for the same reasons (including cross-territorial accessibility; for example, where American consumers now have more access to "foreign" content).

Individually and collectively, authors and publishers of books, journals, film and television, recorded music and music publishing, entertainment (e.g., video games), and business software are serving the needs of the consuming public, in addition to being extremely valuable contributors to the U.S. economy. ${ }^{41}$ Are there valid reasons

38. Hughes, supra note 8, at 386 (citing a September 2, 2014 memorandum from Christopher Sprigman to ALI Dir. Ricky Revesz advocating for the Restatement of the Law, Copyright.).

39. Referring to the social media platforms or search engines alone as the "technology" community does a disservice to the creative community which is just as reliant on (and often innovative of) new technologies for the creation and digital dissemination of their works.

40. The Supreme Court has upheld congressional revisions as promoting the constitutionally required "progress of science" if the revisions either induced the creation of "new works" or the "dissemination" of existing works. See Golan v. Holder, 565 U.S. 302 (2012) (upholding term restorations for non-U.S. works on constitutional grounds); Harper \& Row Publishers, Inc. v. Nation Enters., 471 U.S. 539,558 (1985) ("[C]opyright supplies the economic incentive to create and disseminate ideas.").

41. This according to a December 2020 comprehensive economic report using end-of-year 2019 U.S. government data, prepared by Economists Inc. INT'L INTELL. PROP. ALL., COPYRIGHT INDUSTRIES IN THE U.S. ECONOMY: THE 2020 REPORT (2020) [hereinafter 2020 Economic Report]. According to the 2020 Economic Report, the "core" copyright industries in the United States generated over $\$ 1.5$ trillion of economic output in 2019 , accounting for $7.41 \%$ of the entire economy, and employed approximately 5.7 million workers in 2019 , accounting for $3.79 \%$ of the entire U.S. workforce and $4.46 \%$ of total private 
for improvements to the existing copyright system? Yes, always, but those have more to do with two disparate areas: the need for more effective enforcement in the digital environment and for fairer payment systems overall (including disparities in income for those at the top versus other creators who cannot make a living from their creative output). ${ }^{42}$ However, none of these issues are, or should be, on the agenda for the Restatement.

Instead, the Restatement proceeds along a now five-year controversial journey, leaving creators to fear that the recent gains (pre-COVID) and improvements in the economic ecosystem will backslide if the Restatement law reform agenda succeeds. ${ }^{43}$ The echo chamber effect of incorporating the Rashomon-text Restatement by only one half of the copyright bar will undermine the law, as well as the credibility and authority of the Restatement.

Instead, the ALI should reaffirm its purpose to provide a useful resource for judges and attorneys and, in this particular field of law and business, to take a "do no harm" approach. The entire project has-to date-served only to further polarize the copyright community. Practitioners and courts would be wise to continue to monitor

employment in the United States. Id. at 4. The jobs created by these industries are well-paying jobs; for example, copyright industry workers earn on average $43 \%$ higher wages than other U.S. workers. Id.

42. See, e.g., Dylan Smith, Just 7,500 Artists on Spotify-Out of 8 Million-Make $\$ 100,000$ or More Annually, DigiT. Music NEWS (Feb. 24, 2021), https://perma.cc/PE35-2DW5.

43. See Bill Hochberg, The Record Business Is Partying Again, But Not Like It's 1999, FORBES (Apr. 11, 2019), https://perma.cc/X3XM-2DTP ("Worldwide recording revenue today is only a fraction of what it was at its peak in 1999. In that banner year the industry claimed some $\$ 39$ billion in global revenue, according to the IFPI. In today's dollars, the 1999 sum approaches $\$ 60$ billion, two thirds higher than 2018's revenue harvest of $\$ 19.1$ billion." (citing statistics from the International Federation of the Phonographic Industry)). Compare the protectionist views of copyright by the creative community generally, with an alternative view by current Principal Reporter for the Restatement, Christopher Sprigman (and colleagues). See, e.g., Christopher Jon Sprigman, Copyright and Creative Incentives: What We Know (and Don't), 55 Hous. L. REV. 451, 455-56 (2017) ("I would put it even more directly. Copyright is a tax on learning. It is a tax on culture. It is a tax on speech. And this tax is more than an inconvenience. It is a barrier to those who cannot, or will not, pay it. By pricing some people out of art and literature they would otherwise consume, copyright can impede the spread of learning and culture."); Stefan Bechtold, Christopher Buccafusco \& Christopher Jon Sprigman, Innovation Heuristics: Experiments on Sequential Creativity in Intellectual Property, 91 IND. L.J. 1251, 1255 (2016) ("While some amount of IP protection is deemed essential for creative incentives, too much protection can harm creativity. IP rights create a number of significant social costs, both static and dynamic."); Christopher Sprigman, Reform(Aliz)ing Copyright, 57 STAN. L. REV. 485, 523 (2004) (“Any copyright system that grants exclusive rights, whether based in a utilitarian or natural/moral rights conception, imposes a number of different social costs."); $i d$. at 568 ("[T] he stifling of creativity—as well as free speech—created by the current unconditional copyright regime will only become worse with the passage of time.... [R]eformalization would ensure that creative material lacking commercial value becomes available for reuse immediately."). For more on the potential bias of Christopher Sprigman, see Letter from Adviser Dale Cendali to ALI President David Levi, Re: Council Draft 2 (CD2) (Oct. 15, 2018) ("As the drafts of this project have been released, I have grown increasingly worried that instead of the Reporters creating an impartial, balanced statement of black letter copyright law, meant to be referred to and relied upon by anyone from a beginning law student to a sitting judge, they instead have seized this project as a chance to rewrite that law to fit their own agenda."); Letter from Adviser Dale Cendali to ALI Dir. Richard Revesz, Re: Preliminary Draft 3 (PD3) (Jan. 9, 2018) ("I find myself again disappointed, and increasingly concerned, by the Reporters' apparent refusal to describe the state of copyright law in a fair and unbiased way. In fact, recent events have served only to heighten my concern that at least this Section [2.03 of PD3] of the draft restatement is straying far afield from neutrally reporting on the state of the law."). 
the progress of the Restatement project. But it is not too late to correct course. The ALI has an opportunity to retool this project into a useful exercise for its intended audience-judges and lawyers. It can trim out all of the statutory (Rashomon-text) reworkings, and stick to its historic strong suit: an unbiased and polished synopsis of case law interpreting the actual statute and the common law niches of copyright in a Restatement of the law as it is, not as its drafters purportedly want it to become in the future. If done in a manner that is transparent and fair, with meaningful input from the entire copyright bar of practitioners and judges knowledgeable about the law, it could yet become a useful and credible resource. 